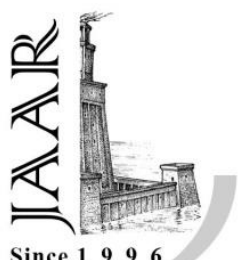

\title{
Degradation Kinetics and Half-Lives of Fenitrothion and Thiobencarb in The New Reclaimed Calcareous Soil of Egypt Using GC-MS
}

\author{
Mohamed R. Fouad ${ }^{1}$, Hamza S. Abou-EInasr ${ }^{2}$, Maher I. Aly ${ }^{1}$, \\ Ahmed F. El-Aswad ${ }^{1}$
}

${ }^{1}$ Department of Pesticide Chemistry and Technology, Faculty of Agriculture, 21545-El-Shatby, Alexandria University, Alexandria, Egypt

${ }^{2}$ National Institue of Oceanography and Fisheries (NIOF), Central Laboratories Unit (CLU), Alexandria, Egypt

ABSTRACT: The degradation process of pesticides is one of the mechanisms for losing sush chemical from the soil after application. The persistence, degradation kinetics and half-lives of fenitrothion (insecticide) and thiobencarb (herbicide) in the new reclaimed calcareous soil in Egypt were studied under laboratory conditions. The recovery percentages of fenitrothion and thiobencarb were 89.67 and $88.34 \%$, respectively. The results of degradation kinetics showed that residues of fenitrothion and thiobencarb were rapidly decreased during the first five days after treatment. Residues of fenitrothion and thiobencarb remained on the second day were $72.45 \%$ and $57.63 \%$, while on the fifth day were 37.72 and $47.18 \%$, respectively. Both tested pesticides disappeared very rapidly from the soil following a bi-phasic pattern. According to the graphical and integral methods, the fit model to describe the degradation kinetic of fenitrothion and thiobencarb is the first order model. The rate constant $(\mathrm{k})$ values for degradation of the two pesticides were 0.036 and 0.068 for fenitrothion and thiobencarb, respectively. The estimated values of half-life were 19.36 days for fenitrothion and 10.24 days for thiobencarb. In general, thiobencarb degraded in sandy clay loam soil about twice faster than fenitrothion.

Keywords: Fenitrothion; insecticide; thiobencarb; herbicide; degradation; kinetics; half-life.

INTRODUCTION: The presence of pesticides in water, soil, and air has raised concern for environmental protection. To compensate for transport and degradation losses and to ensure adequate pest control for a suitable period, pesticides are applied at concentrations greatly exceeding those required for control of the target organisms, thus increasing the contamination. Only a part of the applied amount of a pesticide is bioactive, the rest is distributed in the environment (Kovacević et al., 2011). The biological availability (the resultant impact on non-targetorganisms), behaviour, persistence, and eventual decomposition of soil-adsorbed insecticides are, to a large extent, influenced by their adsorption-desorption phenomena, mobility, leaching and diffusion in the soil matrix (Bailey and White, 1970; Sundaram et al., 1997).

Among all pollutants, pesticides are the most dangerous contaminant for human being and biological diversity because of their negative impacts (Ayranci and Hoda 2005). It was reported that the agrochemicals used on rice are the third consumed in the world with an approximate $9 \%$ of the global market share and demand for these pesticides will continue to grow. Substantial quantities of pesticides used in rice crop and their projected increase raise major concern about their impact on the environment and human health (Anyusheva et al., 2016). Pesticides are used to increase and control the crop yield by farmers for many years. Although much benefit is obtained from their uses, they have some undesirable side effects such as toxicity, carcinogenicity and mutagenicity (Becker and Wilson 1980; Kouras et al., 1998). Among newly developed pesticides, organophosphate and carbamate group of pesticides are most commonly used due to their good selectivity and inexpensive cost (Armaghan and Amini 2008). However, these pesticides are reported as highly toxic and carcinogenic for human being by WHO (2004).

Organophosphate pesticides (OPs) were discovered as toxic nerve agents. They kill insects by disrupting their brains and nervous systems. Unfortunately, it was discovered in 1932 that OPs can cause neurotoxic effects in humans such as cholinergic syndrome, intermediate syndrome, and organophosphate-induced delayed polyneuropathy (Jokanovic and Kosanovic, 2010; U.SEPA, 1999). Fenitrothion can extensively be detected in the environment (Wang et al., 2012; Oiwa et al., 2020). Moreover, the kinetic analysis indicated that degradation of fenitrothion followed a first order reaction irrespective of the soil and water regime (Adhya et al., 1987). Another toxic pesticide group, carbamate group pesticides, thiobencarb which belong to the carbamothioates group, is extensively used in the paddy fields. Thiobencarb is relatively immobile and accumulates in the upper layers of the soil. Laboratory and greenhouse studies have shown that about $93 \%$ (in unsaturated flow) to $70 \%$ (in saturated flow) of thiobencarb remains in the 
upper one $\mathrm{cm}$ soil layer after leaching, indicating strong adsorption of thiobencarb (Braverman et al., 1990; Doran et al., 2008). Adsorption on soil particles can prevent the dissipation of herbicides in aquatic media and prolong their half-lives. Half-life is a significant indicator of herbicide dissipation in the natural environments. This parameter is frequently used to manage herbicide application and irrigation programs. Different halflives have been reported for thiobencarb in paddy fields water, ranging from 5 to 9 days in California (Ross and Sava, 1986; Mabury et al., 1996); 12 days in Spain (Redondo et al., 1994) and 16 to 21 days in Australia (Quayle et al., 2006). Studies have shown that half-life is significantly increased in the adjacent of soil particles. In flooded soils, half-life of thiobencarb has been determined to be 100 to $200 \mathrm{~d}$ in Australia, $100 \mathrm{~d}$ in Japan, and $200 \mathrm{~d}$ in the US (Quayle et al., 2006). In non-flooded conditions, its half-life has been ranged from 10 to $77 \mathrm{~d}$ (Kawamoto and Urano, 1990; Sudo et al., 2002; Quayle et al., 2006). These relatively large differences in half-life show the effects of environmental conditions.

The longer is the persistence of herbicide the higher is the controlling effect on weeds. Moreover, the herbicide residue may have environmental risk, and may influence rotational crops (Mahmoudi et al., 2011). Among others, adsorption on soil particles and chemical and biological degradation are two major factors that affect the activity and persistence of herbicides in water, soil, and other natural ecosystems. In degradation process, herbicide is however broken down through biological, chemical, and photochemical reactions (Kodaka et al., 2003). Soil $\mathrm{pH}$, temperature, moisture, and organic matter content are the major factors that influence chemical and microbial degradation (Mabury et al., 1996).

The objectives of this work were to assess the persistence, degradation kinetics and the halflives of fenitrothion and thiobencarb under laboratory conditions in the new reclaimed soil (calcareous soil) located in from Elnahda region, Elamria, Alexandria Governorate, Egypt.

\section{MATERIALS AND METHODS \\ Tested pesticides}

Fenitrothion (Insecticide), O, O-dimethyl O-4nitro-m-tolyl phosphorothioate. The chemical structure is shown in Figure (1). Solubility in water $0.038 \mathrm{~g} / \mathrm{L}$, Hexane $24 \mathrm{~g} / \mathrm{L}, \mathrm{P}$ value: 0.57 . Technical $97.0 \%$ a.i. Production Company: Shandong Chuangying Chemical Co., China. It is used for controlling chewing and sucking insects on rice, orchard fruits, vegetables, cereals, cotton, and forest. Also fly, mosquito, and cockroach control in public health programs.

Thiobencarb (Herbicide), S-4-Chlorobenzyl diethyl thiocarbamate. Chemical structure is shown in Figure (1). Solubility in water 0.030 g/L, Hexane: 500 g/L, P value: 1.70 X 104 . Technical $97.0 \%$ a.i. Production Company: Shandong SanYoung Industry Co., Ltd, China. It is a pre-emergence and early post-emergence herbicide for weed control in rice paddy fields and other situations.<smiles>COP(=S)(OC)Oc1ccc([N+](=O)[O-])c(C)c1</smiles>

Fenitrothion<smiles>CCN(CC)C(=O)SCc1ccc(Cl)cc1</smiles>

Thiobencarb

Figure 1. Chemical structures of tested pesticides

\section{Tested soil}

The kind of soil used in the current experiment was calcareous from the new Egyption reclaimed. The soil samples were collected from the surface layer $(0-20 \mathrm{~cm})$ from different locations in Elnahda region, Elamria, Alexandria Governorate. The soil samples had no history of pesticide applications. The physical and chemical properties were determined at the Department of Soil and Water Sciences, Faculty of Agriculture, University of Alexandria and the data are presented in Tables 1 \& 2. Soil was air-dried, ground and passed through a $2-\mathrm{mm}$ sieve prior to use. The soil texture was determined by the hydrometer method (Gee and Bauder, 1986). Soil $\mathrm{pH}$ was determined using $0.01 \mathrm{M}$ calcium chloride $(\mathrm{CaCl} 2)$ in a 1:2 w/w soil: solution slurry. The OM content was determined by dichromate oxidation according to the WalkleyBlack method (Nelson et al., 1996). 
(JAAR) Volume: 26 (1)

Table (1): Physical properties of the tested soil

\begin{tabular}{ccccc}
\multicolumn{2}{l}{ Particle size distribution (\%) } & \multicolumn{2}{c}{ Texture class } & WHC (mL) \\
\hline Clay & Silt & Sand & & 38 \\
\hline 20 & 13 & 67 & Sandy clay loam & 38 \\
\hline
\end{tabular}

Table (2): Chemical properties of the tested soil

\begin{tabular}{cccccc}
\hline $\begin{array}{c}\mathrm{EC}(\mathrm{m} \mathrm{mohs} / \mathrm{cm}) \\
\text { at } 25^{\circ} \mathrm{C}\end{array}$ & $\mathrm{pH}$ & $\begin{array}{c}\text { OM } \\
(\%)\end{array}$ & $\begin{array}{c}\text { Total carbonate } \\
(\%)\end{array}$ & $\begin{array}{c}\text { Total soluble cations } \\
(\mathrm{meq} / \mathrm{L})\end{array}$ & $\begin{array}{c}\text { Total soluble anions } \\
(\mathrm{meq} / \mathrm{L})\end{array}$ \\
\hline 5.03 & 8.15 & 1.54 & 44.64 & 60.30 & 50.30 \\
\hline
\end{tabular}

Chemicals and Instrumentation

Anhydrous sodium sulfate (Na2SO4), sodium hydroxide $(\mathrm{NaOH}), \quad$ commercial solvents including acetonitrile and acetone were purchased from Algomhoria Chemical Co., Alexandria, Egypt. Solvents HPLC-grade methanol, dichloromethane, n-hexane and acetonitrile were purchased from Sigma Aldrich Co. (Spruce Street, Louis., MO, USA).

GC-MS a thermo Scientific gas chromatograph GC Trace 1300 coupled with an EI Mass spectrometer ISQ 7000 model (Thermo Scientific USA) equipped with Thermo TR-50 MS capillary column (30 m in length $\times 250 \mu \mathrm{m}$ in diameter $\times$ $0.25 \mu \mathrm{m}$ in thickness of film).

Sonicator, Mod: LBS 2 4, 5Lt; Cod: 616.1020.05; Ser. $N^{\circ}$ : B133276; Year: 2013.

Rotary evaporator bibby scientific limited stone. Staffordshire. St15 0SA. UK.

Centrifuge, Model 90-1 UK.

Water distillatory, DESA 0035, Eu.

Digital balance, ViBRA AJ-320E, 0.01-150 g, Japan.

\section{Pesticide determination and recovery by GC- MS}

GC standard solution

To prepare stock solutions of individually tested pesticides, the standards of fenitrothion and thiobencarb were dissolved in methanol-HPLC (1000 mg/L), considering standard purity, by accurately weighing individual analytical standards into volumetric flasks, dissolving and diluting them to volume with methanol and stored at $4^{\circ} \mathrm{C}$ in the dark. The working standard solution was freshly prepared by appropriately diluting multiple stock solutions with dichloromethaneHPLC. The standard solution $(100 \mu \mathrm{g} / \mathrm{mL})$ was determined immediately before the samples.

\section{Determination by GC-MS}

Fenitrothion and thiobencarb residues in soil samples of degradation experiment were quantitively analyzed using GC-MS, a Thermo Scientific gas chromatograph GC Trace 1300 coupled with an EI Mass spectrometer ISQ 7000 model (Thermo Scientific USA). Spectroscopic detection by GC-MS involved a electron ionization system that utilized high energy electrons $(70 \mathrm{eV})$; MS transfer line temperature $300{ }^{\circ} \mathrm{C}$ and ion source temperature $300{ }^{\circ} \mathrm{C}$. Pure helium gas $(99.995 \%)$ was used as the carrier gas with flow rate of $1 \mathrm{~mL} / \mathrm{min}$. The initial temperature was set at $60^{\circ} \mathrm{C}$ for $2 \mathrm{~min}$, then increased to $100{ }^{\circ} \mathrm{C}$ at a rate of $10{ }^{\circ} \mathrm{C} / \mathrm{min} \mathrm{kept}$ for $5 \mathrm{~min}$, then with $10{ }^{\circ} \mathrm{C} / \mathrm{min}$ to $150{ }^{\circ} \mathrm{C}$ and kept for $5 \mathrm{~min}$, then with $10{ }^{\circ} \mathrm{C} / \mathrm{min}$ to $200{ }^{\circ} \mathrm{C}$ and kept for $5 \mathrm{~min}$, then with $10^{\circ} \mathrm{C} / \mathrm{min}$ to 250 ${ }^{\circ} \mathrm{C}$ and kept for $20 \mathrm{~min}$. One microliter of the prepared extracts was injected in a splitless mode.

\section{Recovery assay by GC-MS}

Untreated soil samples were homogenized and spiked with standard solutions of fenitrothion and thiobencarb (75 $\mu \mathrm{g} / \mathrm{g})$. The samples were processed similar to the procedure of treated samples. Results of the pesticides in degradation experiment were corrected according to the recovery rate. Blank analyses were performed in order to check interference from the matrix (Redondo et al., 1994; Camara et al., 2020).

\section{Degradation study \\ Soil treatment}

The degradation of fenitrothion and thiobencarb in clay soil was monitored under laboratory conditions. A weight of $150 \mathrm{~g}$ soil was placed in 500-mL glass bottle and treated with each tested pesticide (75 $\mu \mathrm{g}$ a.i. /g soil). Three replicates were made for each treatment. The tested pesticides were dissolved in an amount of distilled water equals to $60 \%$ of water holding capacity (WHC) of the tested soil. The solution was added to the soil to reach an adequate concentration of 75 $\mu \mathrm{g} / \mathrm{g}$. All bottles were incubated at $25{ }^{\circ} \mathrm{C}$ for up to 84 days. Through the incubation period, the appropriate amount of water was added to replace lost soil moisture (Fouad, 2017; Badawy et al., 2017). 
Extraction and determination of tested pesticides

The soil was sampled at different times $(0,2,5$, $13,20,27,48,55$ and 84 day). The tested pesticides were extracted from air dried soil samples by dichloromethane-HPLC with sonication. The extraction and clean-up of pesticide residues from soil samples were processed according to the procedure described in Figure (2). The residues were analyzed by GCMS (Redondo et al., 1994).

\section{Assessment of half-life values}

Dissipation kinetics of fenitrothion and thiobencarb were investigated, different kinetic models were tested to select the fit model with the data. The degradation rate was obtained from the streight line plot of the 1st-order kinetic model, $\ln \left[\mathrm{C}_{\mathrm{t}}\right]=\ln \left[\mathrm{C}_{\mathrm{o}}\right]-\mathrm{Kt}$. The half life values of tested pesticides were assessed by the following equations (Moye et al., 1987; Badawy et al., 2017; Yuan et al., 2020).

$$
\mathrm{t}_{1 / 2}=\frac{0.6932}{\mathrm{k}}
$$

Where, $\mathrm{k}$ is the dissipation rate, $\mathrm{t}^{1} / 2$ (Half-life) is a time it takes for an amount of a compound to be reduced by half through degradation (Badawy et al., 2017; Fardillah et al., 2020).

$$
\begin{aligned}
& \text { Soil sample (10 g) + Anhydrous sodium sulfate (5 g) } \\
& \text { Add } 30 \mathrm{ml} \text { dichloromethane-HPLC } \\
& \begin{array}{l}
\text { Extracted by sonication } \\
\text { for } 15 \mathrm{~min}
\end{array} \\
& \text { Filtration } \\
& 1 \\
& \text { Extracted by sonication } \\
& \text { for } 15 \mathrm{~min} \\
& \text { Filtration } \\
& \text { I } \\
& \text { I } \\
& \text { Shaking for } 5 \mathrm{~min} \\
& \text { by sonication }
\end{aligned}
$$

Fig. (2): Schematic diagram of extraction and clean-up of tested pesticides from soil

\section{RESULTS AND DISCUSSION}

\section{Recovery of tested pesticides by GC-MS}

To confirm the efficiency of the extraction method and chromatographic analysis for the determination of tested pesticides in soil, recovery experiments were carried out. The soil samples were spiked with a concentration of 75 $\mu \mathrm{g} / \mathrm{g}$ soil fenitrothion and thiobencarb individually. The recovery percentage was calculated according to the following equation;

$$
\begin{aligned}
& \text { Recovery } \% \\
& =\left(\frac{\mu \mathrm{g} \text { pesticide determined } / \mathrm{g} \text { soil }}{\mu \mathrm{g} \text { pesticide add } / \mathrm{g} \text { soil }}\right) \times 100
\end{aligned}
$$

The recovery percentages of fenitrothion and thiobencarb in calcareous (sandy clay loam soil) were $89.67 \%$ and $88.34 \%$, respectively (Table 3 ). The obtained recovery percentages were more than obtained by Redondo et al. (1994) who found that the recovery of thibencarb in different soils was $63 \%$. Similar carbamate recoveries were obtained from soil samples using a traditional method involving liquid-liquid extraction (Leppert et al., 1983; Szeto and Sundaram, 1980). The recovery percentage of fenitrothion in soils was $94 \pm 10 \%$ (Likas and Tsiropoulos, 2007) also, in soil it was 98\% (Roy et al., 1996). The non-extractable residue might be attributed to the formation of the soil-bound residue (Scheunert, 1992), its percentage ranged from 7 to $90 \%$ based on the applied pesticide (Khan and Dupont, 1987). Generaly, the recovery values were used to correct all obtained residue data (Camara et al., 2020).

\section{Table (3): Recovery percentages of fenitrothion and thiobencarb in soil determined by GC-MS}

\begin{tabular}{lcc}
\hline Pesticides & Fenitrothion & Thiobencarb \\
\hline Recovery \% & 89.67 & 88.34 \\
\hline
\end{tabular}

\section{Persistence of tested pesticides in soil}

The persistence of fenitrothion and thiobencarb was investigated in calcareous (sandy clay loam) soil under laboratory conditions. The soil was treated with a concentration of $75 \mu \mathrm{g} / \mathrm{g}$ soil of fenitrothion and thiobencarb individually. Then the treated soil was incubated at $25{ }^{\circ} \mathrm{C}$ and sampled at different times $(0,2,5,13,20,27,48$, 55 and 84 day). After that, the soil samples were extracted, cleaned up and analyzed by GC-MS.

The results in Table (4) summarized the residues of fenitrothion and thiobencarb in soil during 84 days after treatment. Initial residues of fenitrothion and thiobencarb were 67.26 and $66.26 \mu \mathrm{g} / \mathrm{g}$ soil, while after 48 days, the residues dropped to $8.87 \mu \mathrm{g} / \mathrm{g}$ soil $(13.19 \%$ of the initial residues remaining) and $4.52 \mu \mathrm{g} / \mathrm{g}$ soil (6.82\% of the initial residues remaining). It was observed that the residue of thiobencarb was detected while that of fenitrothion was non-detected at $55^{\text {th }}$ day, however the two pesticide residues were nondetectable at $84^{\text {th }}$ day. It was seen that the residues of the fenitrothion and thiobencarb 
rapidly decreased during the first five days after treatment. Fenitrothion remained at $2^{\text {nd }}$ day was $72.45 \%$ and at $5^{\text {th }}$ day was 37.72. Also, the remain thiobencarb was $57.63 \%$ and $47.18 \%$ at $2^{\text {nd }}$ and $5^{\text {th }}$ day, respectively.

The disappearance curves of fenitrothion and thiobencarb are shown in Figure (3). Within 84 days of incubation, residues of fenitrothion and thiobencarb were monitored in soil samples. The two tested pesticides disappeared very rapidly from the soil following a bi-phasic pattern. Just two weeks after treatment the maximum concentrations of fenitrothion and thiobencarb were reduced to about one third and one fourth. This sharp drop was followed by a period of a slow incremental decrease for five weeks.

Table (4): Residue ( $\mu \mathrm{g} / \mathrm{g}$ soil) and remaining (\%) of of fenitrothion and thiobencarb in sandy clay loam soil determined by GC-MS

\begin{tabular}{ccccc}
\hline \multirow{2}{*}{$\begin{array}{c}\text { Time } \\
(\text { day })\end{array}$} & $\begin{array}{c}\text { Residue } \\
(\boldsymbol{\mu g} / \mathbf{g} \text { soil })\end{array}$ & $\begin{array}{c}\text { Remaining } \\
(\boldsymbol{\%})\end{array}$ & $\begin{array}{c}\text { Residue } \\
(\boldsymbol{\mu g} / \mathbf{g} \text { soil })\end{array}$ & $\begin{array}{c}\text { Remaining } \\
(\boldsymbol{\%})\end{array}$ \\
\cline { 2 - 5 } & 67.26 & 100.00 & 66.26 & 100.00 \\
\hline $\mathbf{0}$ & 48.72 & 72.45 & 38.19 & 57.63 \\
\hline $\mathbf{2}$ & 25.37 & 37.72 & 31.26 & 47.18 \\
\hline $\mathbf{5}$ & 20.29 & 30.16 & 17.86 & 26.96 \\
\hline 13 & 19.28 & 28.67 & 15.08 & 22.77 \\
\hline 20 & 18.30 & 27.21 & 5.94 & 8.96 \\
\hline 27 & 8.87 & 13.19 & 4.52 & 6.82 \\
\hline 48 & ND & - & 0.66 & 0.99 \\
\hline 55 & ND & - & ND & - \\
\hline 84 & & &
\end{tabular}

ND: None-detectable, -: no data

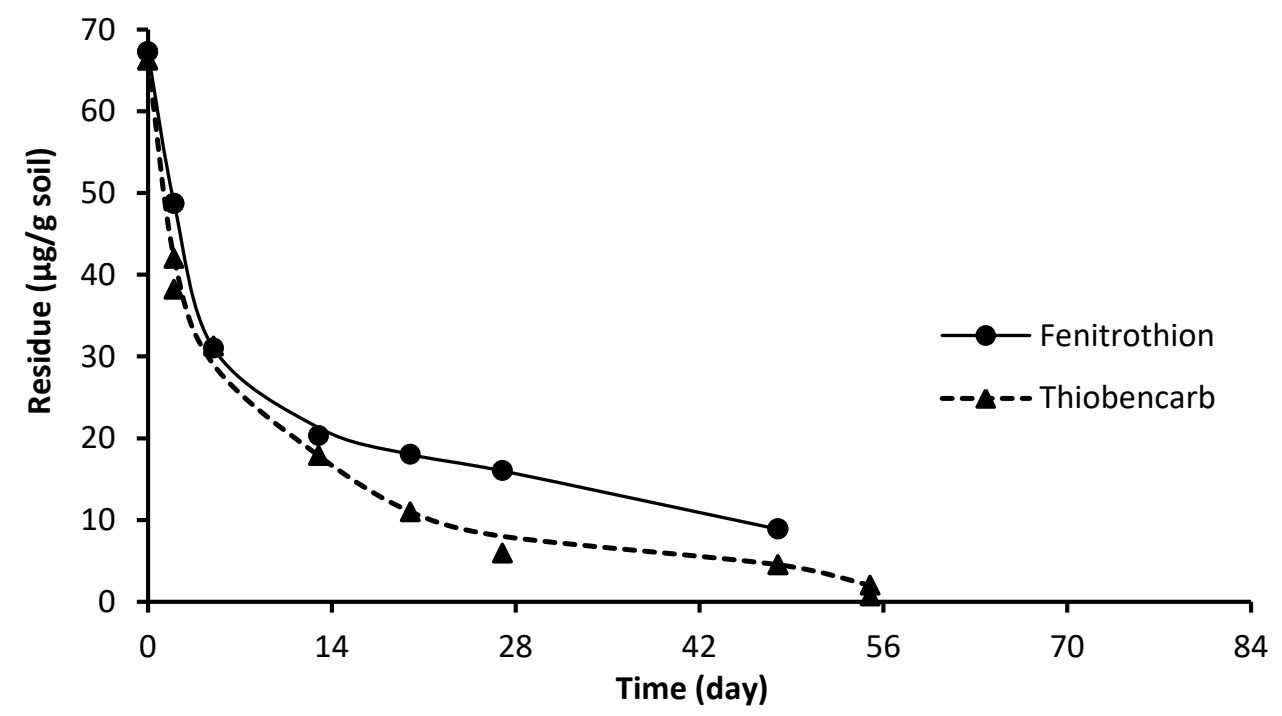

Fig. (4): Disappearance curves of fenitrothion and thiobencarb in soil

Degradation kinetics of tested pesticides in soil To evaluate the decline of fenitrothion and thiobencarb residues in the studied soils, residue data should be subjected to statistical analysis to determine the statistical parameters that describe these processes, as proposed by Likas and Tsiropoulos (2007). Two methods were used to determine the best kinetic model for the degradation data, graphical and integral methods.
A linear regression can be obtained after an appropriate transformation of the residue using different formal models described in Table (5). To select the best fit model, the values of determination coefficient $\mathrm{R}^{2}$ were calculated for each model. As is well known, $\mathrm{R}^{2} \leq 1$, and the larger this coefficient, the better the decline curve fits the data. If $\mathrm{R}^{2}$ becomes negative or zero for any model, then the fit is automatically rejected 
(Lopez-Lopez et al., 2003). Besides, according to the integral method, the correlation is confirmed when SD of calculated $K$ values is a low value. The SD of the $\mathrm{K}$ values were calculated as $\mathrm{K}$ $100 \%$, to compare among thim. It can be seen from Figure (4) and Table (5) the $1^{\text {st }}$ order model give the highest $R^{2}$ value $(0.91)$ and the lowest $\mathrm{SD}$ of $\mathrm{K}$ values (63.47) for thiobencarb. This model gives $\mathrm{R}^{2}$ for fenitrothion $(0.82)$ which is lower than $\mathrm{R}^{2}(0.86)$ obtained by $3^{\text {rd }}$ order model, although the $1^{\text {st }}$ order model gives a lower SD of $\mathrm{K}$ values (60.92) compared to that obtained by $3^{\text {rd }}$ order model (62.44). Therefore, the fit model to describe the degradation kinetic of fenitrothion and thiobencarb is the $1^{\text {st }}$ order model. Various studies have been carried out fitting decline curves in a first-order model for many pesticides (Adhya et al., 1987). However, that interpretation is not always applicable, because the residues frequently diminish quicker at first and much more slowly at a later stage in comparison with the $1^{\text {st }}$-order model (Aguilera-del et al., 1999; Martinez-Galera et al., 2003). Also, it was demonstrated that the degradation of fenitrothion in five different soils followed a first order reaction (Adhya et al., 1987).

Therefore, the degradation kinetics of fenitrothion and thiobencarb were estimated by first-order exponential decay model $\mathrm{C}_{\mathrm{t}}=\mathrm{C}_{\mathrm{o}} \mathrm{e}^{(-\mathrm{kt})}$, where $\mathrm{C}_{\mathrm{t}}$ is the concentration of pesticide remaining in the soil after time $t, C_{o}$ is the initial concentration and $\mathrm{k}$ is the first-order kinetic constant (Fouad, 2017; Badawy et al., 2017). It can be seen from Figure (4) the straight line plot of the $1^{\text {st }}$-order kinetic model, $\ln \left[C_{t}\right]=\ln \left[C_{o}\right]-K t$. The rate constant $(\mathrm{k})$ values for degradation of the two pesticides were 0.036 and 0.068 for fenitrothion and thiobencarb, respectively. The results of linear equation, the rate constant $(\mathrm{k})$ and half-life $\left(\mathrm{t}_{1 / 2}\right)$ of fenitrothion and thiobencarb in soil are shown in Figure (4) and Table (6).

The half-live $\left(t_{1 / 2}\right)$ has been calculated (Table 6) from the $1^{\text {st }}$-order model using equation $\left(\mathrm{t}_{1 / 2}=\right.$ $0.6932 / \mathrm{k})$. It can be seen the estimated values of half-life were 19.36 days for fenitrothion and 10.24 days for thiobencarb. Clearly, the herbicide thiobencarb degraded in sandy clay loam soil faster than fenitrothion. These values are in agreement with the half-life fenitrothion values in the literature, which from 10.5, 10.9 and 20 days in three soils different organic matter (Adhya et al., 1987). Fenitrothion is not persistent because of its rapid degradation by physical, chemical or biological means (Roy et al., 1996). Fenitrothion degraded in upland and submerged soils with a half-life of fewer than 7 days and was of shorter persistence as compared with its half-life of 1228 days under upland conditions and less than 14 days under submerged conditions found by Takimoto et al. (1976). Generally, the degradation process of the pesticides is favoured by the presence of oxygen and by aerobic microorganisms (Khan, 2016). Also, the half-life of thiobencarb is in agreement with previous studies which found that the half-life was 12 days in soil (Redondo et al., 1994). However other studies indicated that the half-life of thiobencarb ranged from 14 to 21 days (Wauchope et al., 1992). The dissipation of the pesticide residues in soil depending on the environmental conditions, type of application, dosage, temperature, $\mathrm{pH}$, and the interval between applications (Khay et al., 2008; Scholz-Starke et al., 2017). It is very important to indicate that the degradation of pesticides under different conditions was recently studied for fenitrothion by Oiwa et al. (2020) and Meng et al. (2019) also, for thiobencarb by Wang et al. (2021) and Guarda et al. (2020). 
Table (5): Determination coefficient $\left(R^{2}\right)$ obtained from the graphical method and standard division (SD) of calculated $k$ values obtained from an integral method for fenitrothion and thiobencarb residues in soil using different kinetic models

\begin{tabular}{ccccc}
\hline \multirow{2}{*}{ Model } & Empirical equation & Pesticide & $\mathrm{R}^{2}$ & $\begin{array}{c}\text { SD of calculated k } \\
\text { (as k 100\%) }\end{array}$ \\
\hline \multirow{2}{*}{ Zero order } & $\mathrm{C}_{\mathrm{t}}=\mathrm{C}_{\mathrm{o}}-\mathrm{kt}$ & Fenitrothion & 0.59 & 78.49 \\
\cline { 3 - 4 } $1^{\text {st } \text { order }}$ & $\mathrm{C}_{\mathrm{t}}=\mathrm{C}_{\mathrm{o}} \mathrm{e}^{-\mathrm{kt}}$ & Thiobencarb & 0.60 & 93.13 \\
\hline \multirow{2}{*}{$2^{\text {nd }}$ order } & $1 / \mathrm{C}_{\mathrm{t}}=\left(1 / \mathrm{C}_{\mathrm{o}}\right)+\mathrm{kt}$ & Fenitrothion & 0.82 & 60.92 \\
\hline \multirow{2}{*}{$3^{\text {rd }}$ order } & $1 / \mathrm{C}_{\mathrm{t}}^{2}=\left(1 / \mathrm{C}_{\mathrm{o}}{ }^{2}\right)+2 \mathrm{kt}$ & Thiobencarb & 0.91 & 63.47 \\
\cline { 3 - 4 } & & Fenitrothion & 0.80 & 69.99 \\
\hline
\end{tabular}

In conclusion, the recovery percentages of fenitrothion and thiobencarb in calcerious (sandy clay loam soil) were very closed. The degradation kinetics showed that the residues of the fenitrothion and thiobencarb rapidly decreased during the first five days after treatment. Residues remained at 2nd day was $72.45 \%$ and $57.63 \%$, at 5th day was 37.72 and $47.18 \%$ for fenitrothion and thiobencarb, respectively. Both tested pesticides disappeared very rapidly from the soil following a bi-phasic pattern. Just two weeks after treatment the maximum concentrations of fenitrothion and thiobencarb were reduced to about one third and one fourth, respectively. This sharp drop was followed by a period of a slow incremental decrease for five weeks. According to the graphical and integral methods, the fit model to describe the degradation kinetic of fenitrothion and thiobencarb is the 1 st order model. The straight line plot of the $1^{\text {st }}$-order kinetic model was $\ln \left[\mathrm{C}_{\mathrm{t}}\right]=$ $\ln \left[\mathrm{C}_{\mathrm{o}}\right]-\mathrm{Kt}$. The rate constant $(\mathrm{k})$ values for degradation of the two pesticides were 0.036 and 0.068 for fenitrothion and thiobencarb, respectively. The estimated values of half-life were 19.36 days for fenitrothion and 10.24 days for thiobencarb. Clearly, the herbicide thiobencarb degraded in sandy clay loam soil about twice faster than fenitrothion. 

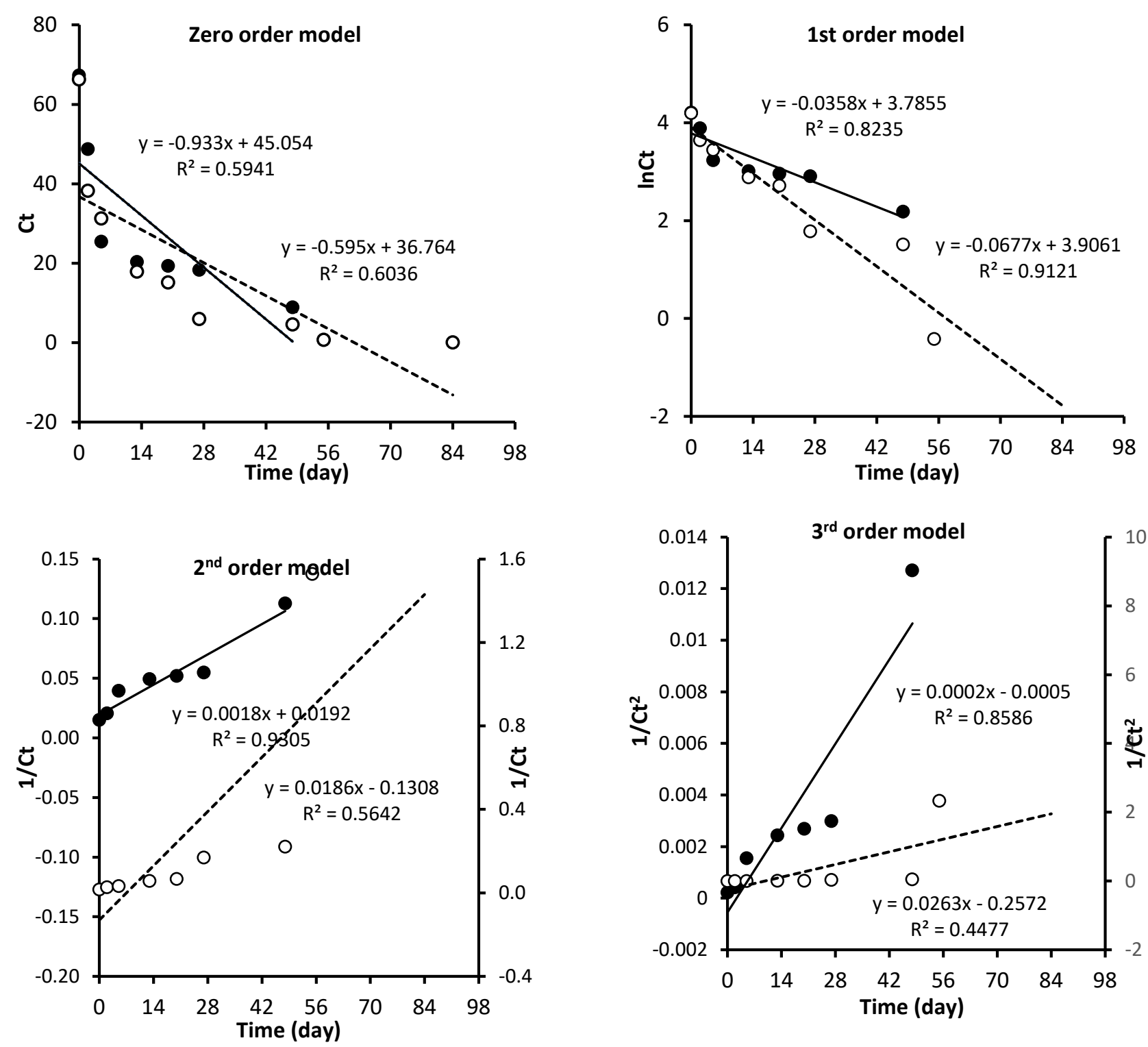

Fig. (4): Plots of different orders rate for degradation of fenitrothion and thiobencarb in soil.

Fenitrothion • Thiobencarb 0

Table (6): Degradation kinetics of fenitrothion and thiobencarb in soil fitted in first-order kinetic model

\begin{tabular}{cccc}
\hline Pesticide & Linear equation & $\mathbf{k}$ & $\mathbf{t}_{1 / 2}($ day $)$ \\
Fenitrothion & $\mathrm{y}=-0.036 \mathrm{x}+3.786$ & 0.036 & 19.36 \\
Thiobencarb & $\mathrm{y}=-0.068 \mathrm{x}+3.906$ & 0.068 & 10.24 \\
\hline
\end{tabular}

\section{REFERENCES}

Adhya T. K.; Wahid P. A.; Sethunathan N. (1987). Persistence and biodegradation of selected organophosphorus insecticides in flooded versus non-flooded soils. Biology and Fertility of Soils. 5(1): 36-40.
Aguilera-del Real A.; Valverde-Garcia A.; Camacho-Ferre F. (1999). Behavior of methamidophos resdues in peppers, cucumbers, and cherry tomatoes grown in a greenhouse: Evaluation be decline curves. Journal of Agricultural and Food Chemistry. 47(8): 33553358. 
Anyusheva M.; Lamers M.; La N.; Nguyen V. V.; Streck T. (2016). Persistence and leaching of two pesticides in a paddy soil in northern Vietnam. Clean-Soil, Air, Water. 44(7): 858866.

Armaghan, M., and M. M. Amini (2008). Adsorption of diazinon and fenitothion on MCM-41 and MCM-48 mesoporous silicas from non-polar solvent. Colloid Journal 71:583-588.

Ayrancı, E., and N. Hoda (2005). Adsorption kinetics and isotherms of pesticides onto activated carbon cloth. Chemosphere 60:1600 1607.

Badawy M. E.; El-Aswad A. F.; Aly M. I. and Fouad M. R. (2017). Effect of Different Soil Treatments on Dissipation of Chlorantraniliprole and Dehydrogenase Activity Using Experimental Modeling Design. International Journal of Advanced Research in Chemical Science. 4 (12): 7-23.

Bailey, G. W. and J. L. White (1970). Factors influencing the adsorption, desorption, and movement of pesticides in soil. Single Pesticide Volume: The Triazine Herbicides, 29-92.

Becker, D. L., and S. C. Wilson (1980). The use of activated carbon for the treatment of pesticides and pesticidal wastes. In Carbon Adsorption Handbook, ed. by P. N. Cheremisinoff and F. Ellebush, 167-212. Ann Arbor, MI: Ann Harbor Science.

Braverman, M.P., S. J. Locascio, J. A. Dusky and A. G. Hornsby (1990). Mobility and bioactivity of thiobencarb. Weed Sci. 38, 607614.

Camara M. A.; Fuster A.; Oliva J. (2020). Determination of pesticide residues in edible snails with QuEChERS coupled to GCMS/MS. Food Additivesand Contaminants. Part A: 1-7.

Doran, G., P. Eberbach and S. Helliwell (2008). The mobility of thiobencarb and fipronil in two flooded rice-growing soils. J. Environ. Sci. Heal. B 43, 490-497.

Fardillah F.; Ruhimat A.; Priatna N. (2020, March). Self regulated Learning Student Through Teaching Materials Statistik Based on
Minitab Software. In Journal of Physics: Conference Series (Vol. 1477, p. 042065).

Fouad M. R. (2017) Behaviour of some pesticides in soil. M. Sc. Thesis. Faculty of Agriculture, Alexandria University.

Gee G. W.; Bauder J. W.; Klute A. (1986). Particle-size analysis. Methods of soil analysis Part 1 Physical and Mineralogical Methods. 383-411.

Guarda, P. M., Pontes, A. M., de S. Domiciano, R., da S. Gualberto, L., B. Mendes, D., A. Guarda, E., and da Silva, J. E. (2020). Determination of Carbamates and Thiocarbamates in Water, Soil and Sediment of the Formoso River, TO, Brazil. Chemistry \& biodiversity, 17(4), e1900717.

Jokanovic, M., and M. Kosanovic (2010). Neurotoxic effects in patients poisoned with organophosphate pesticides. Environmental Toxicology and Pharmacology 29:195-201.

Kawamoto, K. and K. Urano (1990). Parameters for predicting fate of organochlorine pesticides in the environment. 3. Biodegradation rate constants. Chemosphere 21, 1141-1152.

Khan S. U.; Dupont S (1987) Bound pesticide residues and their bioavailability. In: Greenhalgh R.; Roberts T. R (eds) Pesticide Science and Biotechnology. Proc $6^{\text {th }}$ Int Cong Pesticide Chemistry, IUPAC. Blackwell Sci Pub. London. pp 417-420.

Khan, S. U. (2016). Pesticides in the soil environment. Elsevier.

Khay S.; Choi J. H.; Abd El-Aty A. M.; Mamun M. I.; Park B. J.; Goudah A.; Shin H. C.; Shim J. H. (2008) Dissipation behavior of lufenuron, benzoylphenylurea insecticide, in/on Chinese cabbage applied by foliar spraying under greenhouse conditions. Bulletin of Environmental Contamination and Toxicology 81(4):369-372.

Kodaka, R., T. Sugano, T. Katagi, Y. Takimoto (2003). Clay-catalyzed nitration of a carbarnate fungicide diethofencarb. J. Agric. Food Chem. 51, 7730-7737.

Kouras, A., A. Zouboulis, C. Samara, and Th. Kouimtzis (1998). Removal of pesticides from aqueous solution by combined 
physicochemical process-The behavior of lindane. Environmental Pollution 103:193-202.

Kovacević, D., J. Lemić, M. Damjanović, R. Petronijević, D. Janaćković and T. Stanić (2011). Fenitrothion adsorption-desorption on organo-minerals. Applied Clay Science, 52(12), 109-114.

Leppert, B. C.; J.C. Markle, R.C. Helt and G.H. Fujie (1983). J. Agric. Food Chem., 31, 220-223.

Likas D. T.; D. T.; Tsiropoulos N. G. (2007). Behaviour of fenitrothion residues in leaves and soil of vineyard after treatment with microencapsulate and emulsified formulations. International Journal of Environmental and Analytical Chemistry. 87(13-14): 927-935.

Lopez-Lopez T.; Martinez-Vidal J. L.; GilGarcia M. D.; Martinez-Galera M.; Rodriguez-Lallena J. A.(2003). Benzoylphenylurea residues in peppers and zucchinis grown in greenhouses: determination of decline times and pre-harvest intervals by modelling. Pest Management Science. 60: 183190.

Mabury, S. A., J. S. Cox and D. G. Crosby (1996). Environmental fate of rice pesticides in California. Rev. Environ. Contam. Toxicol. 147, 71-117.

Mahmoudi, M., R. Rahnemaie, S. Soufizadeh, M. J. Malakouti, A. Es-haghi (2011). Residual effect of thiobencarb and oxadiargyl on spinach and lettuce in rotation with rice. $\mathrm{J}$. Agric. Sci. Technol. 13, 785-794.

Martinez-Galera M.; Gil-Garcia M. D.; Rodriguez-Lallena J. A.; Lopez-Lopez, J. L.; Martinez-Vidal. (2003). Dissipation of pyrethroid residues in peppers, zucchinis, and green beans exposed to field treatments in greenhouses: evaluation by decline curves. Journal Agricultural and Food Chemistry. 51(19): 5745-5751.

Meng, D., Jiang, W., Li, J., Huang, L., Zhai, L., Zhang, L. and Liao, X. (2019). An alkaline phosphatase from Bacillus amyloliquefaciens YP6 of new application in biodegradation of five broad-spectrum organophosphorus pesticides. Journal of Environmental Science and Health, Part B, 54(4), 336-343.
Moye H. A.; Malagodi M. H.; Yoh J.; Leibee G. L.; Ku C. C.; Wislocki P. G. (1987). Residues of avermectin B1a in rotational crops and soils following soil treatment with $\left[{ }^{14} \mathrm{C}\right]$ avermectin B1a. Journal Agricultural and Food Chemistry. 35: 859-864.

Nelson D. W.; Sommers L. E.; Sparks D.; Page A.; Helmke P.; Loeppert R.; Soltanpour P.; Tabatabai M.; Johnston C.; Sumner M. (1996). Total carbon, organic carbon, and organic matter. Methods of soil analysis Part 3chemical methods. 961-1010.

Oiwa M.; Yamaguchi K.; Hayashi H.; Saitoh T. (2020). Rapid sorption of fenitrothion on didodecyldimethylammonium bromidemontmorillonite organoclay followed by the degradation into less toxic 3-methyl-4nitrophenolate. Journal of Environmental Chemical Engineering. 8 (5): 104000.

Quayle, W.C., D. P. Oliver and S. Zrna (2006). Field dissipation and environmental hazard assessment of clomazone, molinate, and thiobencarb in Australian rice culture. J. Agric. Food Chem. 54, 7213-7220.

Redondo, M.J., M. J. Ruiz, R. Boluda and G. Font (1994). Determination of thiobencarb residues in water and soil using solid-phase extraction disks. J. Chromatogr. A 678, 375379.

Ross, L. J. and R. J. Sava (1986). Fate of thiobencarb and molinate in rice fields. J. Environ. Qual. 15, 220-225.

Roy, S., Kumar, R., Roy, S. and Sharma, C. B. (1996). Biodegradation of fenitrothion in soil. Biomedical Chromatography, 10(2), 60-64.

Scheunert I. (1992): Transformation and degradation of pesticides in soil. In: Chemistry of Plant Protection, Vol. 8 (W. Ebing, ed.-inchief). Springer Verlag, Berlin - Heidelberg New York, pp. 23-75.

Scholz-Starke B.; Egerer S.; Schäffer A.; Toschki A.; Roßig M. (2017) Higher-tier Multi-species Studies in Soil: Prospects and Applications for the Environmental Risk Assessment of Pesticides Ecotoxicology and Genotoxicology. p 31-58.

Sudo, M., T. Kunimatsu and T. Okubo (2002). Concentration and loading of pesticide residues 
in Lake Biwa basin (Japan). Water Res. 36, 315-329.

Sundaram, K. M. S., L. Sloane and R. Nott (1997). Adsorption and desorption kinetics of diflubenzuron and fenitrothion in two different boreal forest soils. Journal of Environmental Science \& Health Part B, 32(1), 1-24.

Szeto, S. Y. and Sundaram, K. M. S. (1980). Simplified method for the analysis of some carbamate insecticides in foliage, forest soil and fish tissue by direct gas-liquid chromatography. Journal of Chromatography A, 200, 179-184.

Takimoto Y.; Hirota M.; Inui H.; Miyamoto J.(1976). Journal Pesticide Science. 1: 131.

Recognition and Management of Pesticide Poisonings, 5th ed. Washington, DC: EPA.

Wang D.; Naito H.; Nakajima T. (2012). The Toxicity of Fenitrothion and Permethrin. F. Perveen (Ed.), Insecticides - Pest Engineering, In Tech, Rijeka, Croatia, pp. 85-98.
Wang, R., Bingner, R. L., Yuan, Y., Locke, M., Herring, G., Denton, D. and Zhang, $M$. (2021). Evaluation of thiobencarb runoff from rice farming practices in a California watershed using an integrated RiceWQ-AnnAGNPS system. Science of The Total Environment, $767,144898$.

Wauchope R. D.; Buttler T. M.; Harnsby A. G.; Augustijn-Beckers P. W. M.; Burt J. P. (1992). The SCS/ARS/CES pesticide properties database for environmental decision-making. Reviews of Springer, Environmental Contamination and Toxicology.123: 1-163.

WHO (2004). The WHO recommended classification of pesticides by hazard and guidelines to classification. International Programme on Chemical Safety, Switzerland.

Yuan S.; Li C.; Zhang Y.; Yu H.; Xie Y.; Guo Y.; Yao W. (2020). Degradation of parathion methyl in bovine milk by high-intensity ultrasound: degradation kinetics, products and their corresponding toxicity. Food Chemistry. 127103.

\section{الملخص العربي}

دراسة حركية تحطم وفترة نصف العمر لمبيدى فينتروثيون وثيوبنكارب فى تربة جيرية من

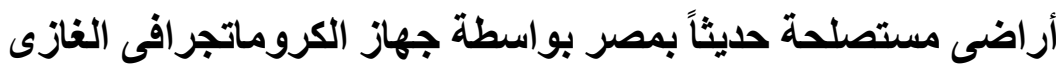

عحم فؤاد ، حمزة أبو النصر' ، ماهر على ، أحمد الأسود

قسم كيمياء وتقنية المبيدات ـ كلية الزر اعة - جامعة الاسكندرية

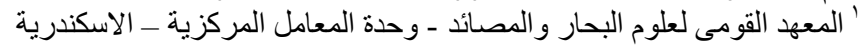

من المعلوم أن عملية تحطم المبيدات هى أحدى ميكانيكيات فقد المبيدات فى التربة. لذا تم در اسة ثبات

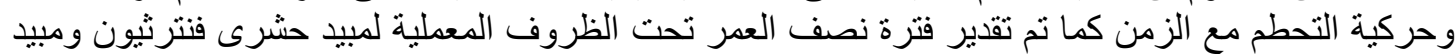

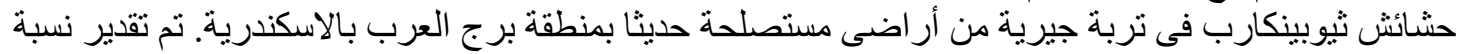

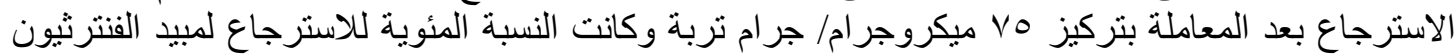

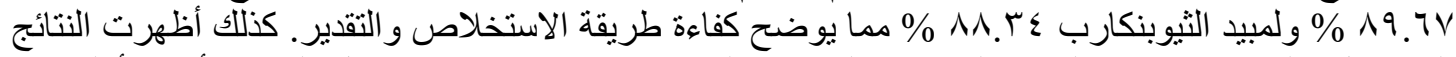

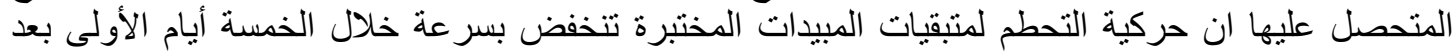

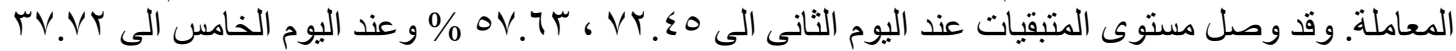

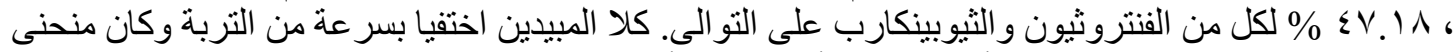
الاختفاء مكون من جزئين الجزء الأول خلال الأسبو عين الأوائل وكان معدل التحطم سريع جدا و الجزء الجئ الثانى خلال الأسابيع التالية وبها معدل تحطم بطيء. للتعرف على النموذج الأنسب لوصف التف حركية التحطم تم اختبار

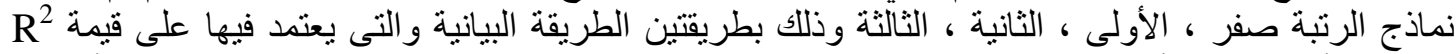

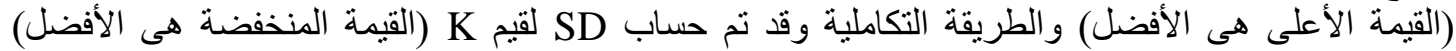

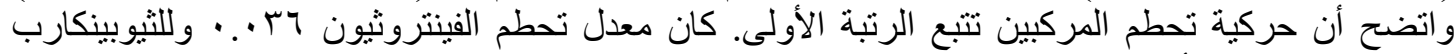

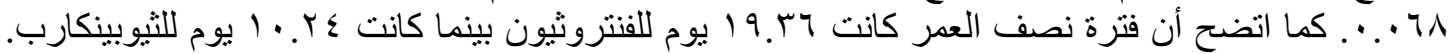
و عموما يمكن القول أن تحطم الثيوبينكارب فى التربة الجيرية كان أسرع بمقدار الضعف عن تحطم الفنتروثيون. 